\title{
Quanto vale uma chanchada? \\ Disputas conceituais e valorativas em torno das comédias cinematográficas brasileiras
} $(1940-50)^{1}$

Guilherme Maia

Euro Prédes De Azevedo

Ao longo das três primeiras décadas do cinema sonoro, no Brasil, foram produzidos 387 longas-metragens de ficção ${ }^{2}$. Cerca de $53 \%$ desses filmes (206) foram comédias, grande parte delas contendo números musicais. Essas comédias, inicialmente chamadas de filmusicais (Augusto 1989; Napolitano, 2009; Vieira 2007b) e musicarnavalescos (Desbois 2016; Ramos e Heffner 2000), produzidas de modo mais sistemático, a princípio, pela Cinédia nos anos de 1930, prosperaram, sofreram transformações ao longo das duas décadas seguintes e entraram para a História do Cinema Brasileiro com o nome de chanchadas. Embora as chanchadas produzidas pela Atlântida tenham deixado marcas mais profundas no discurso historicista, na década de 1950 foram produzidas também por muitas outras companhias cinematográficas, como Cine Produções Fenelon, Flama Filmes, Watson Macedo Produções, Castelo Filmes, Brasil Vita Filmes, Companhia Cinematográfica Franco-Brasileira, Cinelândia Filmes, Unida Filmes, Herbert Richers, Cinedistri, Produções Luiz de Barros, Cinesul, Cinefilmes, Luso Filmes, Art Films, Serrador Companhia Cinematográfica, Nova América Cinematográfica, Companhia Cinematográfica Maristela e Lívio Bruni S.A.

"Ninguém gostava das chanchadas da Atlântida, somente o público"; é o que nos diz a atriz Fada Santoro no documentário Assim era a Atlântida (Carlos Manga, 1975), citando o jornalista Zevi Guivelder. Já uma fala em tom pessoal do pesquisador João Luiz Vieira (2011: 46) declara o lugar das chanchadas na sua memória afetiva, ilustra muito bem essa relação do público com essa classe de filmes:

\footnotetext{
${ }^{1}$ Este artigo é fruto dos projetos de pesquisa "O cinema musical na América Latina: ficção documentários e novos formatos" e "Os musicais no Brasil: cinema e televisão", desenvolvidos no âmbito do laboratório de Análise Fílmica, grupo de pesquisa do Programa de Pós-graduação em Comunicação e Cultura Contemporâneas da Universidade Federal da Bahia. Projetos financiados pela Fundação da Amaro à Pesquisa do Estado da Bahia (Fapesb) e pelo Conselho Nacional de Desenvolvimento Científico e Tecnológico (CNPq).

${ }^{2}$ Dados extraídos do Dicionário de Cinema Brasileiro (Baladi, 2013).
}

RRASILIANA- Journal for Brazilian Studies. Vol. 6, n.1 (December, 2017). ISSN 2245-4373. 
levados por nossa mãe, eu e meu irmão aguardávamos com certa ansiedade e nervosismo as confusões que brotavam das correrias e brigas entre os bandidos. O riso sincero rompia das falas, do jeito de caminhar, das caras e trejeitos de Oscarito, Grande Otelo, Zezé Macedo, Violeta Ferraz, Zé Trindade. As filas para esses filmes eram imensas, com famílias inteiras lotando cada espaço possível das salas de exibição.

Quando a atriz nos diz que "ninguém gostava das chanchadas", refere-se não ao público que lotava as salas e realimentava a indústria do gênero, mas ao modo como a intelectualidade e a crítica cinematográfica da época se manifestavam em relação a esses filmes. De fato, como nos conta Paulo Emílio Salles Gomes (1980: 73), "o fenômeno repugnou aos críticos e estudiosos". Ademais, o próprio nome da coisa - chanchada -, termo substantivo nascido a partir de uma adjetivação pejorativa que "viralizou" no âmbito da crítica jornalística, já nos diz muito sobre a visão de alguns setores da sociedade brasileira do período examinado acerca das comédias das quais tratamos aqui.

Em termos metodológicos, este artigo realiza dois procedimentos que convergem nas considerações finais. O primeiro é o de pôr em evidência as batalhas discursivas em torno desta espécie de ficção cinematográfica dominante no Brasil durante as três primeiras décadas do cinema sonoro, especialmente nos anos de 1950: as chanchadas. Com esse objetivo, é examinado o lugar simbólico das chanchadas no âmbito dos discursos sobre as mesmas, especialmente no marco de um regime interpretativo 'modernista-cinemanovista'. Nos debruçamos também sobre um segundo momento, quando as chanchadas migram do lugar de gênero menor a um outro, sendo reconhecidas não só no que diz respeito a seu valor como obras que encarnam o espírito de um tempo, mas também como filmes engenhosos e importantes na nossa cinematografia, passando a serem vistas por importantes autores como o único gênero genuinamente brasileiro. $O$ segundo procedimento é a análise de duas obras lançadas em 1954: Nem Sansão nem Dalila e Matar ou correr $^{3}$, filmes que nos parecem exemplares para os nossos propósitos: verificar a existência de interfaces entre as obras e as disputas discursivas sobre o valor delas, tendo como unidade de análise os procedimentos paródicos dos dois filmes.

\section{A paródia grotesca e a catarse negativa das chanchadas}

\footnotetext{
${ }^{3}$ Os dois filmes foram dirigidos por Carlos Manga.
} 
Em Cinema no ensino de história: as chanchadas e os anos 1950, Ladenilson Pereira localiza no pensamento crítico e teórico Jean-Claude Bernardet, autor do livro Cinema brasileiro: propostas para uma história, edição original de 19774, a noção de que as chanchadas "não passavam de paródias grotescas da produção cinematográfica estrangeira em geral, e em particular, a norte-americana" (Pereira 2009: 290). A mesma avaliação da natureza paródica das chanchadas aparece em Paródia e chanchada: imagens do Brasil na cultura das classes populares, na seção em que Meirelles (2005) menciona o supracitado texto de Bernardet, desta vez para falar de um efeito de 'catarse do subdesenvolvido': a paródia da chanchada com a função de purgar um suposto (ou não) complexo de inferioridade.

Os dois autores, todavia, não mencionam o nome de Glauber Rocha entre aqueles que exerceram mais influência na construção de uma visão negativa das chanchadas. Em 1963, na sua Revisão crítica do cinema brasileiro, Rocha assume uma postura extremamente agressiva em relação às chanchadas, não vendo nelas qualquer aspecto positivo (Melo 2005). A crítica de Bernardet, quatorze anos depois, faz eco a Rocha em sua rejeição do gênero, variando em cima de esquemas interpretativos sugeridos na base dos seguintes axiomas: 1.as chanchadas são ruins porque são alienantes e fazem o público, miserável que é, rir de sua própria miséria; 2 a catarse ${ }^{5}$ da paródia é do interesse do opressor - do parodiado (mesmo que este não tenha domínio algum sobre a paródia que lhe fazem, nem seja o seu público-alvo); 3. e a catarse destas paródias seria indulgentemente 'auto-depreciadora'. Diferentemente do artigo de Pereira (2009), este trabalho se concentra na figura de Glauber Rocha - não como causa originária, mas como ponto de culminância do discurso antichanchada.

Como se sabe, Glauber ambicionava uma revolução: política (defensor assumido que era da posição de esquerda, anti-imperialista), ética (creditando uma responsabilidade moral ao cinema para com as camadas desfavorecidas em termos socioeconômicos do então chamado Terceiro Mundo) e poética (os filmes devem ter estéticas revolucionárias). Como que ilustrando estes três elementos, em A revolução é um eztetyka, Rocha $\left(1981^{6}\right)$ fala de duas

\footnotetext{
${ }^{4}$ Trata-se, aqui, apenas de informar a data da primeira publicação do texto, para que se entenda a perspectiva cronológica do argumento que segue. A versão utilizada por nós é a de 2009.

${ }^{5}$ A disputa em torno deste termo é intensa, e como este trabalho não tem a intenção de discutir o conceito de catarse, parte de Mendes $(1995,2008)$, para quem a catarse não representa apenas a purgação de emoções, mas sim um circuito entre produção e recepção em que são ativadas inteligências e paixões. Neste sentido, 'catarse' da Chanchada quer dizer, ao mesmo tempo, do ‘efeito’ que se sentiria numa relação puramente fenomenológica com a obra — a graça ou o riso — e do próprio circuito de consumo das chanchadas — traduzido no seu sucesso de público, por exemplo.

${ }^{6}$ Publicado por Rocha em 1967.
} 
'formas concretas' (em suas palavras) desta cultura revolucionária: uma, a didática, deve "alfabetizar, informar, educar, conscientizar as massas ignorantes, as classes médias alienadas"; enquanto a épica deve "provocar o estímulo revolucionário", será "uma prática poética, que terá de ser revolucionária do ponto-de-vista estético para que projete revolucionariamente seu objetivo ético" - "Arte passa a ser, pois, revolução" (Rocha 1981: 66-67.).

Esta brevíssima revisão acerca das proposições cinemanovistas nos serve, aqui, para interpretar Glauber Rocha quando este se pergunta, e responde:

o que havia antes do Cinema Novo? A chanchada, a pornografia, o musicanalhismo etc. O público ia ver estes filmes (ainda vai), se divertia, mas na saída revelava o desgosto diante desta incapacidade ou desleixo da cinematografia nacional (1981: 45-46).

São, portanto, palavras bem fortes - como "pornografia" e "musicanalhismo" - que Rocha utiliza para atribuir valor às chanchadas. Esse regime valorativo, contudo, mais do que um simples julgamento de valor, emerge de uma política discursiva estratégica de um grupo de realizadores que elegeram as comédias dominantes nas telas desde o início do nosso cinema sonoro como o Grande Outro do Cinema Novo. Era preciso libertar o cinema brasileiro da “tirania da chanchada" (Rocha 1981: 15).

Combinamos que nossa grande luta era contra a chanchada; e como o cinema novo merecia crédito, tudo que não era chanchada passava a ser cinema novo para derrubar a chanchada. Dito e feito. [...] A primeira tática, derrubar a chanchada, foi a política do cinema novo (Rocha 1981: 131-132).

Rocha não poupou insultos ao gênero: vulgar (1981: 146), colonizada (1981: 199), miserável (1981: 290), cínica em seu tratamento da miséria (1981: 291), imoral (2003: 170), fundada sobre o pitoresco miserabilista (1981: 100), câncer conformista do sub-desenvolvimento (1981: 321), pornografia a baixo preço (2003: 171). Para além do evidente discurso combativo, é interessante notar a associação de alguns destes termos - 'vulgar', por exemplo, sinônimo de 'comum', 'popular'; ' colonizada', neste caso, dizendo da imitação de aspectos do cinema americano; 'cínica', aqui, faz eco à noção de que "o povo, recebendo na cara a comicidade epidérmica do subdesenvolvimento, acha genial sua própria desgraça e morre de rir" 
(Rocha 1981: 100), ou ainda à de que "quando chegava a chanchada, o povo gostava de rir porque despreza os atores, a história, o som, a música, a moral, a cena, os diálogos e o próprio cinema brasileiro" (Rocha 1981: 288). Os dois últimos trechos - sobre o 'riso' do público das chanchadas -, aliás, parecem mesmo explicitar um desejo de Rocha em 'explicar', tanto o interesse popular pelas chanchadas, quanto o sentido de sua comicidade: 'povo' e 'riso' marcariam, para Glauber, uma perspectiva auto-depreciadora que as chanchadas tinham e que se refletia também numa suposta visão do público acerca de si mesmo e do nosso cinema.

Antes de falar sobre a 'virada interpretativa' pela qual passaram as chanchadas, fazse importante mencionar novamente o artigo Ensino do cinema na história: as chanchadas e a década de 50, original de 2006. Neste artigo - de pouco mais de uma década atrás e reeditado em 2009 - ainda ecoam críticas com o mesmo teor das anteriormente citadas. Tentando observar o fenômeno com "um olhar crítico que suplantasse suas fragilidades facilmente verificáveis" (Pereira 2009: 210), o autor propõe que as chanchadas poderiam ajudar a compreender o período social e político brasileiro da metade do século passado, ou seja, que as chanchadas teriam valor como meio de apreender elementos de um determinado espírito do tempo, mas não por valores intrínsecos aos filmes, que, na opinião de Pereira, são compostos por "números musicais repetitivos, [...] e humor de gosto duvidoso, [...] enredos repetitivos, os roteiros com piadas previsíveis e de duplo sentido" (Pereira 2009: 209); um "humor rasteiro" (Pereira 2009: 216) e "críticas tão óbvias" (Pereira 2009: 210). Arrematando: "as chanchadas, quando vistas com olhos críticos, [...] poderiam ter uma função educadora, didática, expositiva do Brasil de seu tempo". Apenas assim "as paródias podem ser vistas além de seu caráter pretensamente grosseiro e ridículo" (Pereira 2009: 21314).

No diagnóstico de Bernardet (2009) e Rocha (1991, 2003), as chanchadas produziam no espectador um efeito que poderíamos chamar de catarse de autodepreciação, jamais cedendo, neste diagnóstico, à possibilidade de existência de um processo de fruição do gênero que se desviasse deste sentido 'autoflagelatório'. De acordo com os dois autores, a única 'ponderação intelectual' das chanchadas residia nesta - estranha e curiosa - relação com seus espectadores: nós, os filmes, lhes faremos rir de sua própria miséria, e vocês rirão. Não estão muito distantes de Pereira, que credita somente a possibilidade de 'esclarecimento', por via do olhar crítico, grave, arguidor, duro - exterior ao filme, mérito de uma 'leitura inteligente', e jamais mérito das obras do gênero. Adiantando um pouco do que trabalharemos adiante: ora, não veríamos aqui um aniquilamento exatamente do que as 
chanchadas tiveram de mais específico, aquilo com o que mais pareciam se conectar com seu público: o riso, a graça, o entretenimento - além de pressupor, por negação, que estas estratégias de comicidade nada teriam de críticas?

Mesmo em textos posteriores ao debate modernista, e também em alguns que evidenciam o valor paródico das chanchadas, a crítica a estas se dá no sentido de uma imposição do gênero sobre seu público, ressoando tanto Glauber Rocha $(1981,2003)$, quanto Jean-Claude Bernardet (2009). Em Neves, lemos que

a incapacidade de trabalhar criativamente com o novo elemento [o som] provocou então o nascimento das paródias humorísticas, às quais se deu o nome de chanchadas. Esse gênero cinematográfico, bem brasileiro, combinava com o espírito irreverente e incrédulo do nosso público. Passou a ser rentável apesar de artisticamente desprezível (20017: 101).

O autor continua, afirmando que Alberto Cavalcanti, tendo revolucionado o uso do som na Inglaterra, sofreu aqui no Brasil uma desvalorização, sob o determinismo do mau gosto que as chanchadas já haviam sedimentado (Neves 2001: 101), e que as chanchadas seriam dotadas de um "desajeitado expressionismo" (Neves 2001: 103). Mesmo quando tenta abrandar o tom de seu discurso, o valor do gênero se torna claro para o autor, quando diz que "a expressão [chanchada] em si só é pejorativa; mas, afinal, devemos a sua existência ao menos um ponto de referência crítico e alguns cacoetes simpáticos que ainda hoje, vez por outra, pontuam nossos filmes" (Neves 2001: 107).

Uma interpretação filológica deste embate poderia afirmar - e não se equivocaria, cremos - que a ideia de que a chanchada é um objeto 'menor', mesmo tendo Glauber Rocha como figura central, é mais antiga e estaria mesmo no processo em que foi tecida a relação do termo com aquela espécie de filme, da palavra com a coisa. Segundo João Luiz Vieira (1997: 175), o termo chanchada pode ter derivado da expressão italiana cianciata, palavra que pode ser traduzida por 'sem sentido, uma espécie de arremedo vulgar, argumento falso', ou do termo chanza, que conforme nos ensina J. Corominas (1954) em seu Diccionario Critico Etimológico da la Lengua Castellana, significa "burla, broma, mentira, embuste". O fato da nomeação do gênero das chanchadas já ter em si um juízo de valor, na mesma medida em que funda uma linhagem de interpretação, faz reverberar toda uma série de outros juízos acerca de elementos em diálogo com os seus filmes - o popular, o corporal, o cômico, e

\footnotetext{
${ }^{7}$ Originalmente publicado em 1977.
} 
mais. Entretanto, é por meio da dialética Cinema Moderno-Chanchada que se chega à - e ao mesmo tempo se explica a - seguinte síntese que, como vimos, habitou parte considerável dos discursos negativos sobre o gênero: a chachada não seria ruim apenas por incorporar estes elementos, mas por representar 'o outro' de uma agenda poética, ética e revolucionária.

Fabiano Canosa, ao falar de Rio, Quarenta Graus (Nelson Pereira dos Santos, 1955), afirma que, finalmente, um diálogo havia sido estabelecido com o público e com a realidade brasileira "fora dos padrões vulgares da chanchada" (1977: 20). Estes textos, publicados mais de dez anos depois da emergência do modernismo cinematográfico brasileiro e dos livros de Glauber Rocha, apontam para a continuidade de um discurso contra as chanchadas.

\section{O giro valorativo}

Embora a corrente hermenêutica à qual podemos atribuir uma 'virada interpretativa' acerca das chanchadas tenha surgido na segunda metade da década de 1980, é interessante ler a declaração de Adhemar Gonzaga e Paulo Emílio Salles Gomes em livro publicado em 1966, intitulado 70 anos de Cinema Brasileiro: "não há razão para esconder que nos últimos vinte anos do período que estudamos era mesmo a chanchada o que havia de mais estimulante e vivo no cinema nacional" (Gomes e Gonzaga 1966: 89). Em grande parte, é nessa direção que autores como Rafael de Luna Freire (2011), Sérgio Augusto (1989) e João Luiz Vieira (1987, 2000a, 2000b, 2011), além de outros, a exemplo de Gilmar Rocha (2012) e Alcides Ramos Freire (2005), viriam a oferecer novas possibilidades fruitivas e valorativas ao gênero. O termo 'chanchada' - adjetivo pejorativo, segundo Freire (2011) e Vieira (2000b), para quem, lembremos, a palavra esteve sempre ligada "à ideia de falsidade e mentira" (Vieira 2000b: 117) -, que fora utilizado para caracterizar filmes considerados "malfeitos segundo uma particular concepção de qualidade" (Freire 2011: 66), denotaria, hoje, "o principal gênero cinematográfico brasileiro ampla e consensualmente reconhecido como tal por críticos, pesquisadores, jornalistas e também por grande parte do público de cinema brasileiro" (Freire 2011: 66). Neste mesmo artigo, o autor trata da "generificação" da chanchada, demonstrando como este termo passou entre os anos 1940 e 1960 por um "processo de substantivação que, posteriormente, ao longo dos anos 1970 e 1980, o livrou de seu juízo de valor " (Freire 2011: 66), oferecendo suporte para nossa afirmação de que as chanchadas haviam, de fato, passado por um processo de reinterpretação. 
Em relação ao bloco epistemológico anterior a esta 'virada' passada pelas chanchadas, Vieira (2011: 58-59) afirma que,

para um olhar de "primeiro mundo", a chanchada sempre foi pobre, baixa e vulgar nos seus títulos e narrativas, segundo uma crítica que também condenava a picardia sexual, em geral sustentada por diálogos e comportamentos que revelavam preconceitos raciais e de classe. A chanchada era condenada, entre outros argumentos, porque seus enredos "não tinham pé nem cabeça", crítica que assumia, como paradigma, o ideal de coerência narrativa e plausibilidade do cinema dominante, descartando assim uma atitude irreverente em relação ao modelo americano. O poder potencialmente subversivo inerente à dimensão carnavalizada da chanchada só foi compreendido bem mais tarde.

O autor vê a chanchada como um "gênero cinematográfico de ampla aceitação popular que melhor sintetiza e define o cinema brasileiro das décadas de 30, 40 e, principalmente, 50" (Vieira 2000b: 117). Lisa Shaw, pesquisadora da Universidade de Liverpool especialista em História Cultural do Brasil, diagnostica a existência de um valioso caráter antropofágico na essência paródica das chanchadas.

Estes filmes exibiam uma crítica irreverente ao modelo sagrado dominante e apontavam o choque cultural entre a visão hollywoodiana de mundo e a realidade da vida brasileira devorando o original para criar algo novo e autenticamente nacional em essência (Shaw 2007: 69).

Como discutido anteriormente, estas "imitações" foram, de maneira geral, desprezadas pelos críticos e teóricos, pelas mais diversas razões: seu 'mau gosto', presumida ausência de criatividade, o fato de serem, supostamente, resultado de constrições de poder às quais as chanchadas respondiam de modo subserviente, produzindo na instância da recepção algo como uma 'catarse negativa do oprimido'. Já Shaw (2007) pondera que a inocência e a ausência de pretensão desta espécie de filmes, a assunção de sua 'inferioridade' técnica e seu humor autodepreciativo expressam seu brasilianismo intrínseco, o que marcaria a chanchada não apenas como gênero autêntico - autêntico na imitação, autêntico porque falsificado e falsificador, autêntico em sua hibridez -, mas como único gênero 
genuinamente brasileiro.

Para Vieira (2011), apesar da chanchada estar passando por um processo de reinterpretação, os textos que a tomam como objeto têm, em geral, um viés histórico e culturalista, pois "a ênfase tem recaído menos nos aspectos formais e de linguagem do gênero e mais na riqueza de suas representações multiculturais e nas relações com o contexto maior da história brasileira do período" (Vieira 2011: 59-60). O procedimento analítico deste artigo busca inverter essa matriz, dando maior atenção aos aspectos formais e de linguagem.

Vejamos, a seguir, um exercício de análise que vai às obras, atento, em primeiro lugar, a elas mesmas, ou seja, aos seus aspectos internos, visando a detectar o que têm de singular e, a partir desse viés analítico, refletir sobre o modo como as duas posturas valorativas polares, expostas nesta seção do artigo, reverberam (ou não) nos filmes analisados.

\section{Nem Sansão nem Dalila}

O filme nos conta a história do barbeiro Horácio, interpretado pelo comediante Oscarito, que, por acidente, parece ter sido transportado pela máquina do tempo do professor Incognitus von Tempo, juntamente com o amigo Hélio e o professor. Aparentemente, os três vão parar no Reino de Gaza, na terra dos filisteus, exatamente no ano de 1130 antes de Cristo.

Os elementos paródicos estão presentes desde a abertura. Primeiro, os caracteres góticos utilizados nos créditos parecem repetir a mesma estratégia do filme 'copiado', fazendo uma clara referência à ideia das escritas em papiros. Além disso, também na abertura, a música épica da obra brasileira soa curiosamente parecida com a música da versão estadunidense, repetindo um tema arabesco, em tom menor, explorando intervalos de semitom. Se em Samson and Delilah (Cecil B. DeMille, 1949) a composição inicial evoca o tempo e local nos quais se passa a estória, em Nem Sansão Nem Dalila a música ganha ainda um outro sentido, uma nova camada hermenêutica ativada pelo processo paródico, pelo fato de sua melodia ser muito similar à da música do 'original'.

Aqui, cabe breve exegese sobre o lugar da classe intelectual na obra: o professor Incognitus von Tempo é o primeiro personagem a aparecer no filme, numa sequência na qual o vemos falar - não sem um risível sotaque estrangeiro, aparentemente alemão sobre seu mais novo invento, como que numa conferência de imprensa. Assim como em outras chanchadas, especialmente em Carnaval Atlântida (José Carlos Burle, 1952), 
personagens que representam o estereótipo do "intelectual" são configurados como seres "rebaixados", programados para nos fazer rir deles. Evidentemente, o nome do professor - Incognitus - se dá ao riso, uma vez que denota um intelectual, um homem do saber, cujo próprio nome significa 'algo que não se sabe', destacando um desencontro entre nome e coisa, termo e função. A forma latina, ao invés do significante em português, 'incógnito', realça a possibilidade desta interpretação, apontando para as chamadas antiguidades clássicas e para o lugar de destaque intelectual que estas ocuparam e ocupam na cultura. Enquanto o professor exibe sua máquina do tempo, um dos intelectuais que o observa põe um par óculos por cima de outros, que já estavam em seu rosto, como que para 'ver melhor' o que está a ser mostrado. A imagem parece ridícula, a ideia de dois óculos sobrepostos parece absurda, desnecessária - criando uma espécie de hipérbole da 'máscara' do intelectual; se este já é sobremaneira representado usando óculos, nesta sequência de Nem Sansão Nem Dalila vemos a caricatura da caricatura.

\section{A paródia anti-heroica}

Faz-se importante observar o personagem de Oscarito, Horácio, seja em sua composição física, seja em suas disposições de caráter, para entender de que forma estratégias paródicas são engendradas pela obra. Logo ao começo do filme, o vemos chegar tarde ao trabalho e inventar estórias para que seu patrão não lhe culpe; quando ocorre uma briga entre Horácio e outro personagem, aquele foge com medo deste; assim que Horácio tem a oportunidade, torna-se um ditador bonachão em Gaza, distribuindo penas jurídicas e taxações governamentais as mais absurdas - um 'taxímetro' nos camelos, por exemplo - sobre as atividades comerciais de seus súditos. Além disso, é franzino, pequeno; nas palavras de alguns personagens do filme, tem o "corpo de mosquito", "esquelético", é "mirrado espécime". Horácio é um sujeito anti-heroico, na medida mesmo em que o termo designa um herói às avessas: é fisicamente fraco e moralmente dúbio.

Horácio consegue uma força física descomunal por meio de uma troca não muito justa: quando este encontra o Sansão mítico e acende um cigarro em sua frente, deixa-o espantado com sua habilidade de fazer fogo. Assim, Sansão troca sua peruca, aquilo que lhe fora divinamente oferecido, por um isqueiro. A estratégia é a de fazer de Horácio a versão chanchadesca do mito. A força, que havia sido concedida por Deus ao herói Sansão, agora encontra-se no franzino Horácio, e não mais para combater inimigos da Fé ou vencer leões com as próprias mãos. Aqui, a força de Sansão é redirecionada para os anseios pessoais do 
personagem pícaro/malandro, cuja tendência representa "o reverso dos grandes heróis épicos [...]: um herói cuja grandeza é não ter grandeza nenhuma" (Feijó 1985: 24). O rebaixamento do herói mítico, clássico, é feito pelas características 'moralmente baixas' do personagem de Oscarito, mas também pelo seu próprio corpo: a pantomima, o humor físico do seu personagem e a sua própria configuração anatômica invertem características sedimentadas de um certo tipo de herói - o nobre, altivo e forte Sansão - oferecendo um anti-herói por meio da paródia do mito.

Em outra cena, Horácio começa um discurso com a frase "trabalhadores de Gaza...", num tom empostado, arrastado, o que alude a Getúlio Vargas e ao bordão de abertura de seus discursos: "trabalhadores do Brasil". Nesse sentido, também aqui a paródia se faz por meio da mesma estratégia, ou seja, a de 'rebaixar' um herói - um herói nacional, como poderia ser lida a representação oficial/institucional de Vargas à época. Não é à toa que muito da crítica política deste filme se dá em referência a Vargas, figura mais significativa no cenário político nacional do período. O personagem de Horácio, por conta do temor que todos têm de sua força, se torna um ditador e começa a ampliar o alcance do poder governamental, criando departamentos, impostos, penas. O humor atravessa também essa paródia: a imponente construção da persona de Vargas é satirizada nos termos de um ditador sonso, inapto, parvo, que toma decisões políticas totalmente disparatadas, mas que encontram ressonância numa corrente crítica da Era Vargas, fazendo do exagero e do absurdo seu mecanismo cômico: "fica estabelecido que todos os dias do ano serão feriados, com exceção do dia do trabalho" e "para bom andamento do meu governo, fica instituída a burocracia" são alguns dos ditos de Horácio que dão sustentação a esse argumento, além do já citado artifício de transpor, de rebaixar a figura de um líder governamental a um bufão, um burlesco, um histrião da pantomima.

Outro aspecto útil a esta análise parece fazer coincidir o anti-herói, no filme, com a noção que Gonzalez (1994) oferece do herói pícaro. Para o autor, parece ser a perspectiva marginal e paródica do anti-herói pícaro que determina e impõe as outras características formais, narrativas etc. - do romance picaresco. Este tipo de romance "tende a se afastar consideravelmente do que poderia ser um modelo 'realista' de escrita, abrindo espaço para a presença de ficções dentro de ficções" (González 1994: 334). Em Nem Sansão, nem Dalila, numa das cenas iniciais, vemos Horácio e seu amigo Hélio em uma fuga automobilística; a montagem paralela entre estas sequências de fuga e as do professor Incognitus a explicar o funcionamento de sua máquina do tempo parecem sugerir um encontro iminente, e é o que acontece: Horácio bate com o carro numa parede próxima à máquina do professor, que já 
estava sendo acionada. Na banda sonora, entram harpas e volta a melodia arabesca, sugerindo, como já dissemos, local e tempo, mas, neste momento, sugerindo também a entrada no mundo do sonho de Horácio.

O que vemos, após a imagem do carro sobre a máquina e enquanto estes recursos sonoros são ativados, é uma outra cena, em um local selvagem, com o jipe batido, quando Horácio acorda. Há, aqui, dois mundos: um é o mundo comum, cotidiano da vida do personagem, seu trabalho, seus atrasos e as reclamações do patrão; outro é um mundo absolutamente onírico, e é exatamente neste mundo onírico que a fantasia do filme toma parte. Não apenas o superpoder de Sansão, mas toda uma série de insights cômicos, como a presença do rádio, da TV, de diversos departamentos governamentais de um estado moderno em um tempo que antecede o próprio Cristo funcionam, em seu absurdo, na chave onírica. Mesmo a própria paródia engendrada pelo filme - seja a paródia da outra obra, Samson and Delilah, seja a de Vargas, seja a do herói mítico - está dentro das (e responde às) regras aparentemente mais frouxas deste confuso mundo criado pela natureza picaresca de nosso protagonista.

\section{Matar ou correr}

A estratégia de anunciação da inclinação paródica ao início de Matar ou correr, nos créditos, se assemelha à de Nem Sansão nem Dalila, em especial no que tange ao uso da tipografia. No caso de Matar ou correr, a fonte utilizada faz referência a uma espécie de fonte muito comum nos filmes de western, a uma convenção do gênero. Além disso, uma mensagem escrita ainda nos créditos nos informa que "este filme foi realizado em certo ponto do oeste, e em época qualquer. Para facilidade do trabalho de nossos artistas e melhor entendimento por parte do público, a língua falada é a 'Portuguesa com Certeza'". Além disso, esta mensagem funciona como dispositivo autorreflexivo, uma vez que faz a obra apontar não apenas para si mesma como constructo, mas para toda uma linhagem de obras ligadas ao western e também, como vemos em seu título, para um outro filme específico, High noon (Fred Zinnemann, 1952), que teve como título no Brasil Matar ou morrer. A imagem sobre a qual lemos os créditos é a de um grande plano geral de um oeste mítico, com um cowboy armado sobre o topo de um cânion escarpado; o próprio nome do filme, com 'correr' ao invés de 'morrer', diz ainda destas propensões paródicas e, ao mesmo tempo, cômicas: como veremos mais abaixo, as disposições físicas e de caráter da dupla protagonista é antagônica em relação ao que é comum nos westerns, cujos protagonistas são pintados com cores de 
heróis míticos, corajosos. Ao invés do binômio matar-morrer, os anti-heróis do filme aqui analisado, por ausência destas características morais, escolheriam facilmente a simples fuga, quando a outra possibilidade fosse apenas a da morte.

É interessante também notar alguns elementos constitutivos do mundo intertextual da paródia que a obra propõe: os cenários a imitar construções presentes nos filmes americanos - mas que parecem algo exagerados, numa finalização tosca que evidencia e caçoa, pelo excesso, da diferença entre os cenários mais bem acabados do gênero estadunidense, como no caso do saloon de Matar ou correr; da presença de um índio nativo americano fortemente estereotipado em seus traços visuais e adereços (como o cocar de penas no cabelo, além da vestimenta e da própria pose de seu corpo, rígida e de braços cruzados), que surge em tela, por cerca de quatro segundos, apenas para ser envenenado e tombar ao chão; de um vilão hipermexicanizado de nome Gringo, usando sombrero, poncho e que cavalga entoando uma canção no que parece ser uma mistura de espanhol e português; do duelo final marcado na linha do trem; dos cowboys supermasculinizados no saloon; e do vilão, de nome Jesse, numa referência a Jesse James, um fora-da-lei americano que ficou famoso tanto na sua vida real quanto nas suas múltiplas representações em narrativas sobre o 'oeste selvagem'.

A recomposição material do mundo do velho-oeste, realizada evidenciando aspectos da distância técnica entre Matar ou correr e o modelo imitado, cria mesmo uma ambiência farsesca, artificial, exagerada - estratégia comuns nas paródias. Já os outros elementos citados parecem fazer uma crítica cômica a certos preconceitos do western em relação ao latino, ao índio norte-americano, e a alguns dos cacoetes mais comuns do gênero, como a noção de um 'vilão total', encarnado no personagem Jesse Gordon, que acende cigarros com tiros de pistola (interpretado por José Lewgoy, que, por sua vez, já tinha longa tradição em representar vilões no cinema brasileiro).

\section{A paródia anti-heroica, outra vez}

Já em uma das sequências iniciais de Matar ou correr, temos apresentada algumas questões morais ou de caráter em torno dos protagonistas Kid Bolha (Oscarito) e Cisco Kada (Grande Otelo): ambos estão cercados por um grupo que os acusa de serem 'vigaristas'; um dos que acusam conta que a dupla lhe vendeu uma caixa de gafanhotos, fingindo tratar-se de camarão seco, e logo depois, uma personagem feminina surge, montada a cavalo, afirmando que Kid Bolha havia prometido casar-se com ela, mas fugiu. A multidão oferece a Kid Bolha 
o casamento ou a forca, ao que ele escolhe a forca. Finalmente, a multidão decide pelo casamento, quando Kid Bolha propõe um brinde à ocasião e a dupla envenena seus opositores. Mais ou menos na metade do filme, quando já estão na cidade de City Down, a dupla de protagonistas encontra o vilão, Jesse Gordon, e joga cartas contra ele no saloon. Após uma confusão, o personagem de Oscarito, num golpe de sorte, faz cair o lustre do estabelecimento sobre o vilão, de maneira que este fica impossibilitado de levar a mão ao coldre da arma. São aclamados pelos presentes e Kid Bolha é posto no lugar do falecido xerife da cidade - o sétimo que o vilão Jesse Gordon já assassinara.

É nas figuras dos personagens Oscarito e Grande Otelo, vestidos de homens-da-lei, que a inversão se faz; os personagens, dois fora-da-lei, passam ao lugar da figura de poder oficial, exatamente o personagem que, no gênero norte-americano, representa a vigilância e a punição da civilização contra os "fora-da-lei". Entretanto, poderiam ser, eles mesmos, aqueles de quem o xerife deve defender a cidade. Como em Nem Sansão, nem Dalila, a pantomima sinaliza esta inversão: os dois, vestidos com toda uma indumentária séria, trabalham o corpo na tradição do humor físico, impondo às figuras de autoridade uma gestualidade de palhaços. A arma de fogo torna-se parte deste corpo comicamente convulsivo e vemos Kid Bolha atirar enquanto gesticula, para todo lado, com total inconsequência.

Uma outra inversão também se dá em relação aos papéis fundamentais de determinados personagens. Se, no western, pode-se mesmo tolerar personagens de 'alíviocômico', é fato que não são estes a protagonizar a estória - seja no que tange à sua importância narrativa, seja mesmo no 'tempo de tela'. Entretanto, o 'mocinho' de Matar ou correr, que é um funcionário do estado que chega a City Down para ajudar a prender Jesse Gordon e que tem um enlace amoroso com uma moça da cidade, não tem quase nenhum destaque narrativo na obra. A 'anástrofe' paródica, no filme analisado, se dá na medida em que os personagens de Oscarito e Grande Otelo - que, num filme de western, teriam lugar possível como alívio cômico, em função do tensionamento dramático do gênero - podem ser percebidos como o centro e a força motora daquela particular narrativa, ao invés do 'mocinho' ou do par romântico. A resolução do conflito, ou seja, prender os vilões da cidade, não parece ser aquilo que o filme deseja oferecer ao espectador como fundamental. É importante para o fechamento do filme, mas, em relação às estratégias cômicas, a obra concede muito pouco espaço para o desenvolvimento desta trama, que se torna quase que um esquete, como se, desta vez, fosse a comédia a convocar 'alívios dramáticos'.

Nesta tentativa de lançar luz a alguns aspectos formais de dois filmes bastante 
significativos da Chanchada, tínhamos duas intenções. Primeiramente, acreditávamos e queríamos demonstrar que as estratégias narrativas e estéticas dos filmes podem sinalizar, elas mesmas, marcas da disputa conceitual acerca da chanchada, seja quando acusada de ser um gênero 'menor', seja, opostamente, em sua celebração. Também se ensejava observar o gênero por meio de um método de análise que destoasse um pouco do paradigma histórico e contextual que, como visto em Vieira (2011), predomina nos estudos dos filmes das chanchadas. Abaixo, propomos algumas considerações sobre estes pontos.

\section{A paródia como centro da disputa}

A questão da paródia surge, mais de uma vez, na revisão bibliográfica feita neste trabalho, citada nominalmente ou mesmo nos termos de suas estratégias. Como vimos no primeiro bloco de interpretações, a paródia das chanchadas é observada negativamente por Rocha (1981, 2003), Bernardet (2009), Pereira (2009), Neves (2001), Canosa (1977). No segundo grupo, emerge positivamente de noções como 'dimensão carnavalizada ${ }^{8}$ da chanchada', mencionada por Vieira (2011), ou no 'devoramento do original para criar o novo' proposto por Lisa Shaw (2007).

A primeira corrente nos parece inclinada a uma perspectiva epistêmica frankfurtiana da arte, valorizando um trabalho 'anti-industrial', que destoe das formas da 'cultura de massa'. Além disso, todo o argumento centralizado em Rocha $(1981,2003)$ se embasa sobre um direcionamento sociológico da análise dos filmes, até mesmo normativo, sugerindo o que o cinema brasileiro deveria ser e o que não deveria sê-lo, e a 'catarse do oprimido', mencionada por Rocha e Bernardet, presumidamente gerada pela paródia da chanchada, reitera este ponto de vista. A segunda corrente é percebida aqui como um ponto no processo de mudanças mais amplas pelas quais passou a análise do produto da cultura, ao menos a partir da ascensão dos Estudos Culturais. Por meio do enfraquecimento da fronteira entre 'Alta' e 'Baixa' cultura; de uma revisão crítica dos cânones a partir de análises que os colocavam como resultado da história; de uma 'recapitalização' de objetos culturais considerados 'menores'; de um renovado interesse pelo 'popular' e pelo 'massivo', entre outras razões, este segundo enfoque se pauta na ideia de que as chanchadas eram, tecnicamente, os filmes que podiam ser, e que a apropriação estético-paródica desta deficiência técnica em relação ao cinema americano, por exemplo, é um sinal de vigor

\footnotetext{
${ }^{8}$ Termo que remete estética da carnavalização proposta por Bakhtin (2010), que observa a paródia como inversão de um hegemonicamente 'alto' por outro, 'baixo'.
} 
poético das chanchadas, e não o contrário, como teria defendido a primeira corrente de interpretações.

Os procedimentos paródicos extraídos de nossas análises podem ser vistos como formas de apropriação textual em que os elementos parodiados são redesenhados ao exagero, caricaturados, ridicularizados. O herói clássico, o Brasil varguista/o próprio Presidente, o intelectual, o western, tudo isso é revisitado por Nem Sansão nem Dalila ou por Matar ou correr, mas também está presente nas argumentações da revisão bibliográfica: basta considerar, no caso do primeiro agrupamento interpretativo, o quão caro à mitologia glauberiana é o herói clássico, como no caso de Deus e o diabo na terra do sol (Glauber Rocha, 1964). Quanto à paródia crítica da situação política nacional do período, lembremos da noção de 'catarse negativa', ou seja: de que o povo riria de sua própria miséria e de uma presumida superficialidade dessa críticas nos filmes. Em relação ao tratamento que se dá aos intelectuais, encontramos sua 'versão discursiva' e polarizada na valorização do erudito em Bernardet (2009) e, mais significativamente, no próprio espírito intelectualista do Cinema Novo de Rocha, exemplificado especialmente em Terra em Transe (Glauber Rocha, 1967). Ligado especificamente ao western, a própria abominação à cultura industrialamericana, unida ao desejo por um cinema nacional, servem de argumento ao primeiro bloco: se a agenda negava o internacionalismo imperialista, isto seria algo a ser criticado nas chanchadas.

O segundo bloco, do outro lado do espectro valorativo, observa pelo menos dois destes aspectos ao interpretar as chanchadas: o da crítica e da imitação. A crítica realizada pelos filmes não é considerada superficial, mas postura política: castigat ridendo mores ${ }^{9}$. $\mathrm{O}$ que Pereira (2009) chamara de 'crítica superficial' ganha, no segundo bloco da interpretação da chanchada, o valor de uma crítica poderosa, voltada contra a sanha estatizante do período, por exemplo. Além disso, a já citada assunção de inferioridade técnica - vista, é evidente, dentro de uma ótica específica do que seria 'bom' e 'ruim' em cinema - passa a ser lida não como inútil e auto-depreciadora, mas como processo por meio do qual o cinema nacional pensava o próprio cinema nacional, e com isso, também, o cinema internacional, a condição do país, o 'subdesenvolvimento'.

\section{Outros caminhos interpretativos}

\footnotetext{
${ }^{9}$ Expressão latina que significa algo como 'corrige-se aos costumes rindo destes', supostamente cunhada pelo poeta francês Abbé Jean de Santeul.
} 


\section{O riso pelo riso}

Como vimos, Glauber Rocha e Bernardet, em suas críticas, tinham especial preocupação em 'explicar' o riso e a constância das grandes plateias das chanchadas, reduzindo mesmo o primeiro - de manifestação quase sempre inequívoca ${ }^{10}$ do prazer - a um processo de expurgo da miséria por parte do 'povo'. O revisionismo posterior viu este riso e nos processos com os quais tal riso era alcançado como crítica contundente, ou seja, o oposto daquilo que havia sido dito anteriormente. Aqui, propõe-se uma outra chave interpretativa, conquanto não seja especialmente complexa: a de que as configurações cômicas das chanchadas e o riso que geravam poderiam, sim, ser um sistema em si, sem a necessidade de uma disposição de crítica social para se legitimar - ainda que tal crítica existisse nos filmes.

Note-se a rara presença de obras de tendência cômica no Cinema Novo ${ }^{11}$, ausente, aliás, da obra de seu principal autor, e ainda o tom trágico de alguns dos filmes cinemanovistas, manifesto em sua obra maior, Deus e o diabo na terra do sol ${ }^{12}$. Os cinemas modernos ao redor do mundo, em especial a Nouvelle Vague e o Neorrealismo italiano, se inclinam ao cômico, ainda que não de maneira exclusiva e considerando ainda que podem, em certas obras, flertar com o trágico; mesmo o movimento moderno que sucede o Cinema Novo no Brasil, o chamado Cinema Marginal, tem fortes marcas de uma comicidade, ainda que outra, diferente daquela das chanchadas. Neste aspecto, a estética cinemanovista destoa daquela dos seus 'primos' europeus e do seu 'irmão mais novo', o Cinema Marginal. Se o Cinema Novo responde a uma tradição do gênero 'sério', se não faz rir, podemos perceber uma conexão entre a inclinação poética do movimento e o discurso anti-cômico pautado por ideais cinemanovistas.

Quanto a este artigo, nos parece que é o riso que confere aos filmes analisados o seu sabor mais singular; é o cômico - corporal, de caráter, seja nas piadas verbais, na inversão heroica via pantomima - é a comédia que permite, por meio de estratégias poéticas, caçoar da seriedade e nos oferecer seu oposto, aquilo que se presume ser o que Aristóteles atribuiria como efeito ao gênero cômico em sua Poética: a graça. Se, por um lado, encontra-se evidência textual, em obras do gênero, de uma paródia crítica, não nos parece necessário investir este procedimento de 'razões superiores', ou seja, afirmar a validade cômica das chanchadas

\footnotetext{
${ }^{10}$ Em Mendes (2008) é sugerida a possibilidade do 'riso nervoso', que surge de uma situação que nada teria de cômica.

${ }^{11}$ Macunaíma (Joaquim Pedro de Andrade, 1969) e Azyllo muito louco (Nelson Pereira dos Santos, 1970) são algumas destas raras obras de natureza cômica no Cinema Novo.

${ }^{12}$ Sobre a inclinação trágica em Glauber Rocha, $C f$. VILLAÇA, 2002 e BENTES, 2002.
} 
pelo seu valor crítico. Não se trata, aqui, de 'peneirar' o que há de comentário político daquilo que seria o 'cômico puro' (o que quer que isso venha a ser). Trata-se de observar aquilo que se dá à graça, nos filmes, em sua justa proporção no que tange à construção poética destas obras, para que se pudesse falar do que é cômico nas chanchadas sem que, necessariamente, este argumento tivesse de se subordinar à ideia de 'esclarecimento'. Em tempo, e à guisa de provocação: por que, diferentemente do que se faz, não se sugere a crítica como meio para o cômico?

\section{As chanchadas como cinema moderno}

Apesar do fato de que, como vimos, o cinema moderno brasileiro, encarnado na figura de Glauber e do movimento cinemanovista, ter feito das chanchadas o seu grande outro, queremos levantar uma possibilidade, no mínimo, curiosa: a de que as chanchadas respondem, sim, a certas exigências estéticas e políticas modernas/modernistas. A questão muito frequente, nas chanchadas, da relação nacional-estrangeiro, no nível temático; e a própria paródia, no nível estético, evocam preocupações políticas e formais dos artistas de 22, sendo uma corrente que vai desaguar mesmo na segunda fase do cinema moderno nacional, a do Cinema Marginal e da Estética do Lixo ${ }^{13}$. Uma outra estratégia muito cara ao modernismo cinematográfico - tanto na Nouvelle Vague quanto no Cinema Marginal, por exemplo - é a da autorreflexividade, de uma arte que expressa sobre si mesma. Este movimento anti-dramático, no sentindo de que quebra um modelo narrativo hegemônico, pode ser visto em abundância nos filmes analisados, mas sua principal manifestação se dá na medida em que emulam, via exagero, outros filmes e gêneros: é no aspecto caricatural que as obras analisadas fazem emergir uma espécie de autoconsciência textual, cultuado objeto de diversos modernismos. Se havia, ao menos no meio da intelligentsia brasileira, um desejo por uma estética moderna, que seria buscada pelos cinemas Novo e Marginal, é notável que as chanchadas, antecipando elementos modernos (seja no tema da cultura nacional vs. estrangeira, seja na forma das paródias), tenham passadas despercebidas - ou sido deliberadamente negadas - por críticos e teóricos nestes seus aspectos inclinadamente modernistas.

\footnotetext{
${ }^{13}$ Sobre a hipótese de uma reativação de elementos paródicos da Chanchada pelo Cinema Marginal, ver Chanchada e a estética do lixo, artigo que analisa algumas "estruturas retóricas retrabalhadas da chanchada a partir de dois clássicos do cinema brasileiro (pós) moderno, Macunaíma e $\mathrm{O}$ bandido da luz vermelha. A permanente influência desses dois textos fílmicos destaca processos de carnavalização e paródia, marcas estilísticas da chamada estética do lixo" (VIEIRA, 2000a, p. 169).
} 


\section{Bibliografia}

Aristóteles. 2000. "Poética". Tradução de Eudoro de Souza. Coleção Os Pensadores: Aristóteles, v. II. São Paulo: Abril Cultural, p. 245-286.

Augusto, Sérgio. 1989. Este mundo é um pandeiro: a chanchada de Getúlio a JK. São Paulo: Cinemateca Brasileira/ Companhia das Letras.

Bakhtin, Mikhail. 2010. A Cultura Popular na Idade Média e no Renascimento: o contexto de François Rabelais. São Paulo: Hucitec.

Baladi, Mauro. 2013. Dicionário de filmes brasileiros: filmes de longa-metragem produzidos entre 1909 e 2012. São Paulo: Martins Fontes.

Bentes, Ivana. 2002. Terra de fome e sonho: o paraíso material de Glauber Rocha. http://www.bocc.ubi.pt/pag/bentes-ivana-glauber-rocha.html Acessado em 03/03/2016.

Bernadet, Jean-Claude. 2009. Cinema brasileiro: propostas para uma história. São Paulo: Companhia das letras.

Canosa, Fabiano. 1977. "Cinema brasileiro: ontem, hoje e amanhã”. Revista Cultura. Ano 6, n.24, jan/mar, p.8-21.

Catani, Afrânio Mendes e S., José I. de Melo. 1983. A chanchada no cinema brasileiro. São Paulo: Brasiliense.

Corominas Joan; Pascual, José A. Diccionario crítico etimológico castellano e hispánico. Madrid: Editorial Gredos, 1980.

Desbois, Laurent. 2016. A odisseia do Cinema Brasileiro. São Paulo: Companhia das Letras.

Freire, Rafael de Luna. 2011. “Descascando o abacaxi carnavalesco da chanchada: a invenção de um gênero cinematográfico nacional." Revista Contracampo, n. 23, p. 66-85.

Freire, Alcides Ramos. 2005. “Historiografia do cinema brasileiro diante das fronteiras entre o trágico e o cômico: redescobrindo a "Chanchada"." Fênix - Revista de História e Estudos Culturais, p. 1-15. 
Gomes, Paulo Emílio S. 1980. Cinema: Trajetória no Subdesenvolvimento. 2.ed. Rio de Janeiro: Paz e Terra.

Gonzaga, Adhemar e Gomes, Paulo Emílio S. 1966. 70 anos de cinema brasileiro. Rio de Janeiro: Expressão e Cultura.

González, Mario. 1994. A saga do anti-herói: estudo sobre o romance picaresco espanhol e algumas de suas correspondências na literatura brasileira. São Paulo: Nova Alexandria.

Meirelles, William Reis. 2005. Paródia E chanchada: imagens do Brasil na cultura das classes populares. Eduel.

Mendes, Cleise Furtado. 2008. A gargalhada de Ulisses: a catarse na comédia. São Paulo: Perspectiva.

Mendes, Cleise Furtado. 1995. As estratégias do drama. Salvador: Centro Editorial e Didático da UFBA.

Napolitano, Marcos. 2009. “O fantasma de um clássico: recepção e reminiscências de Favela dos Meus Amores (H. Mauro, 1935)." Significação: Revista de cultura audiovisual. V. 36, nº32, p. 137-57.

Neves, David. 2001. "Por uma estética cinematográfica brasileira." Cinemais: Revista de cinema e outras questões audiovisuais, $\mathrm{n}^{\mathrm{o}}$ 31, Setembro/outubro, ps. 39-51. (Originalmente publicado em 1977).

Neves, Luiz Felipe B. 1974. “A ideologia da seriedade." Revista de Cultura Vozes, ano, v. 68, p. 32-41.

Pereira, Ladenilson José. 2009. "Cinema no ensino de história: as chanchadas e os anos 1950." Cadernos de Pós-Graduação, v. 5, n. 1, p. 207-218.

Ramos, Augusto e Hefner, Hernani. 2000. “Cinédia”. In: Ramos, Fernão e Miranda, Luís Felipe (org.). Enciclopédia do Cinema Brasileiro. São Paulo: Editora Senac, p. 130-132.

Rocha, Glauber. 1981. Revolução do cinema novo. Rio de Janeiro: Alhambra, 1981.

Rocha, Glauber. 2003. Revisão crítica do cinema brasileiro. São Paulo: Cosac Naify, 2003. (Originalmente publicado em 1963). 
Rocha, Gilmar. 2012. "Eternos vagabundos: malandros, palhaços e caipiras no mundo da chanchada." Projeto História. Revista do Programa de Estudos Pós-Graduados de História, V. 43, 2012.

Shaw, Lisa. 2007. "A imitação cultural na chanchada: o caso de Quem roubou meu samba? e Rio, Zona Norte." Revista Alceu, v. 8, n. 15, p. 69-81.

Vieira, João Luiz. 1987. A chanchada e o cinema carioca (1930-1955). In: Ramos, Fernão Fernão. História do Cinema Brasileiro. São Paulo: Art Editora.

Vieira, João Luiz. 2000a. “Chanchada e a estética do lixo." Revista Contracampo, nº 05, p. 16982

Vieira, João Luiz. 2000b. "Chanchada" (verbete). In: Ramos, Fernão Pessoa e Miranda, Luiz Felipe (orgs.). Enciclopédia do cinema brasileiro. São Paulo: SENAC Editora.

Vieira, João Luiz. 2011. O corpo popular, a chanchada revisitada, ou a comédia carioca por excelência. Revista Acervo, v. 16, n. 1, p. 45-62.

Vieira, João Luiz. 2007. Cinema Brasileiro Marginal: humor, paródia e chanchada às avessas. In: Bragança, Gustavo; Freire, Rafael de Luna e Boillet, Rodrigo. A invenção do cinema marginal. Rio de Janeiro: Tela Brasilis.

Villaça, Mariana Martins. 2002. "América Nuestra: Glauber Rocha e o cinema cubano." Revista Brasileira de História, v. 22, n. 44, p. 489-510.

Xavier, Ismail. 2001. O cinema brasileiro moderno. Rio de Janeiro: Paz e Terra. 